\title{
Sistem Pentautan Citra Udara Menggunakan Algoritme SURF dan Metode Reduksi Data
}

\author{
Zaki Hamizan*1, Raden Sumiharto ${ }^{2}$ \\ ${ }^{1}$ Program Studi Elektronika dan Instrumentasi, FMIPA UGM, Yogyakarta, Indonesia \\ ${ }^{2}$ Departemen Ilmu Komputer dan Elektronika, FMIPA UGM, Yogyakarta, Indonesia \\ e-mail: *11 zaki_hamizan@yahoo.co.id, ${ }^{2}$ r_sumiharto@ugm.ac.id
}

\begin{abstract}
Abstrak
Salah satu cara pentautan citra udara dapat menggunakan algoritme SURF (Speeded Up Robust Features). Algoritme ini memiliki ketahanan terhadap perubahan skala, rotasi, blurring, pencahayaan, dan perubahan bentuk. Namun sebagian hasil dari deteksi keypoint SURF tidak selalu dianggap sebagai keypoint yang menarik sehingga perlu dieliminasi.

Sistem yang dibuat menggunakan detektor SURF pada proses pendeteksian. Metode reduksi data mengeliminasi keypoint yang dianggap saling berdekatan. Kemudian dilanjutkan dengan proses deskripsi keypoint dengan deskriptor SURF. Hasil deskripsi selanjutnya dicocokkan menggunakan FLANN. Tahap selanjutnya adalah pencarian pola matriks homograf dengan RANSAC dan pentautan citra dengan menumpuk keypoint menggunakan warpPerpective.

Pengujian sistem pentautan dilakukan dengan beberapa variasi citra masukan, yaitu variasi skala, rotasi, dan overlap. Berdasarkan hasil pengujian, metode Reduksi data yang diterapkan memiliki nilai radius minimal optimum pada rentang 40 piksel hingga 100 piksel. Proses komputasi tetap dapat dikerjakan dengan reduksi jumlah keypoint hingga 90\% dari jumlah awal keypoint. Rata-rata waktu komputasi dengan menggunakan metode reduksi data $39,41 \%$ lebih cepat daripada tanpa metode reduksi data.
\end{abstract}

Kata kunci-FLANN, RANSAC, eliminasi keypoint, radius minimal

\section{Abstract}

One of the algorithm for aerial image stitching system is SURF (Speeded Up Robust Features). It is a robust algorithm which is invariant to image scale, rotation, blurring, illumination, and affine transformation. Although SURF has good performance, some of the detected keypoints are not always considered as necessary keypoints. As a result, these unnecessary keypoints are needed to be eliminated to decrease computation time.

The proposed system uses SURF detector in the detection process. The data reduction method will eliminate couple of keypoints which have near distance each other. Next, the keypoints will be described by SURF descriptor.The description Results further matched using FLANN. The next step is the search pattern with RANSAC homography matrix and stitch the picture to accumulate keypoints using warpPerpective.

Stitching system are tested with some variations, such as scale variations, rotation variations, and overlap variations on the image. Based on the result, the proposed Data Reduction method has optimum value of minimal radius from 40 pixels to 100 pixels. The stitching process is still working with up to $90 \%$ keypoint number reduction. Average computation time using data reduction method are $39,41 \%$ faster than without data reduction method.

Keywords - FLANN, RANSAC, keypoint elimination, minimal radius 


\section{PENDAHULUAN}

D ewasa ini perkembangan teknologi telah membawa kemajuan dalam berbagai aspek kehidupan manusia. Salah satu teknologi yang menarik perhatian dalam perkembangannya adalah teknologi pengolahan citra. Pengolahan citra dapat dikerjakan menggunakan alat, seperti kamera yang diinstalasikan pada UAV (Unmanned Aerial Vehicle), yang digunakan untuk mengambil citra pada area uji untuk kebutuhan analisis sehingga memungkinkan peneliti mendapatkan informasi-informasi yang diperlukan [1].

Proses pengambilan citra udara harus dilakukan berulang untuk mendapatkan citra dengan cakupan area yang luas [1]. Hasil dari pengambilan citra udara tersebut berupa citra yang terpisah antara satu citra dengan citra yang lain. Citra yang sudah diambil dapat ditautkan dengan menggunakan algoritme SURF (Speeded Up Robust Features) [2]. Algoritme ini bekerja dengan menentukan titik acuan (keypoint) dari sebuah citra yang nilainya tetap ketika mengalami perubahan skala, rotasi, blurring, pencahayaan, dan perubahan bentuk [3,4,5].

Walaupun algoritme SURF memiliki kemampuan yang baik dalam proses deteksi keypoint, sebagian hasil dari deteksi tersebut tidak selalu dianggap sebagai keypoint yang menarik pada citra yang diujikan [6]. Oleh sebab itu, keypoint tersebut hanya akan menambah waktu komputasi pada algortima SURF sementara dalam prosesnya, setidaknya hanya dibutuhkan 4 pasang dari hasil pencocokan keypoint antar citra supaya proses pentautan citra dapat dilakukan. Dengan demikian keypoint yang tidak menarik perlu dihilangkan [6].

\section{METODE PENELITIAN}

\subsection{Analisis Sistem}

Pada penelitian ini dibuat sistem yang mampu mentautkan citra udara dengan tampilan citra terbatas, menjadi sebuah keluaran yang menghasilkan tampilan citra dengan cakupan area yang lebih luas.

Sistem yang dirancang membutuhkan dua buah masukan citra pada setiap prosesnya. Citra pertama merupakan citra uji yang diatur sedemikian sehingga dapat dilakukan pengujian sedangkan citra kedua merupakan citra acuan yang ukuran dan bentuknya tidak dirubah. Kedua citra udara yang selesai diakuisisi akan ditemukan keypoint dari masing-masing citra dengan algoritme SURF. Jumlah keypoint yang terdeteksi akan dieliminasi sebagian dengan metode reduksi data. Setelah jumlah keypoint citra sudah tereduksi, dilakukan proses deskripsi keypoint untuk dicocokkan dengan kedua citra udara. Setelah proses tersebut selesai maka hasil pencocokkan akan menjadi acuan untuk melakukan pentautan kedua citra. Gambar 1 menunjukkan blok diagram rancangan sistem pentautan citra udara.

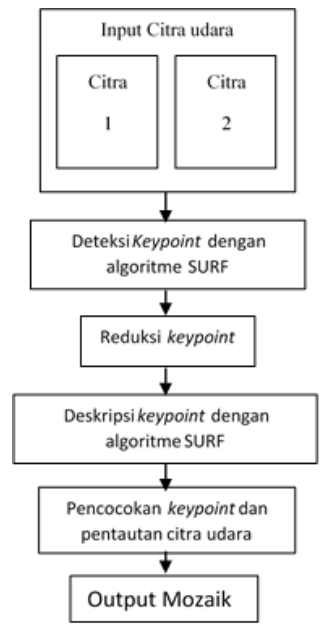

Gambar 1 Diagram blok sistem pentautan citra udara 


\subsection{Peralatan}

Peralatan sistem yang digunakan untuk mendukung proses penelitian ini terdiri dari perangkat keras dan perangkat lunak yang masing-masing memiliki spesifikasi sebagai berikut.

\section{2.1 Spesifikasi Perangkat Keras}

1. Prosesor AMD Vision A4 Dual-Core $1,9 \mathrm{GHz}$

2. RAM 4GB DDR3

3. GPU AMD Radeon ${ }^{\mathrm{TM}}$ HD $6480 \mathrm{G}$

\section{2.2 Sistem Perangkat Lunak}

1. Sistem operasi Linux Ubuntu 14.04 LTS sebagai sarana pengoperasian sistem

2. IDE Geany dengan pustaka OpenCV 3.1.0 yang telah terintegrasi di dalamnya sebagai compiler program

\subsection{Rancangan Perangkat Lunak}

Sistem yang dirancang merupakan sistem yang dapat mentautkan dua buah masukan citra udara pada setiap prosesnya sehingga akan diperoleh hasil pentautan berupa citra dengan cakupan yang lebih luas. Berikut merupakan diagram alir sistem pentautan citra udara yang ditunjukkan pada Gambar 2.

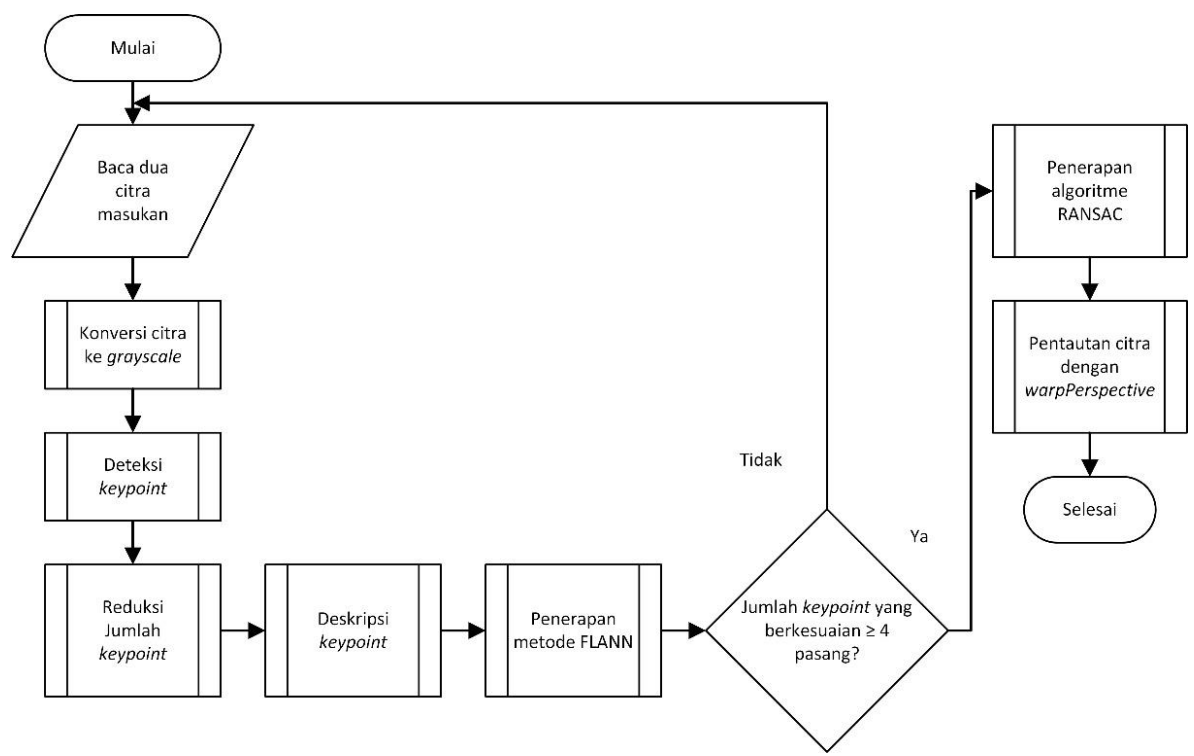

Gambar 2 Diagram alir sistem secara keseluruhan

Citra udara yang selesai diakuisisi akan ditemukan keypoint dari masing-masing citra dengan algoritme SURF. Kemudian keypoint yang terdeteksi akan dieliminasi sebagian dengan metode reduksi data. Setelah jumlah keypoint pada citra sudah tereduksi, dilakukan proses deskripsi keypoint dengan deskriptor SURF. Keypoint pada kedua citra masukan yang sudah dideskripsi kemudian dicocokkan menggunakan FLANN. Hasil pencocokkan tersebut akan dijadian acuan untuk mencari matriks homograf menggunakan RANSAC dimana matriks tersebut akan digunakan dalam proses warpPerspective. Hasil dari proses warpPerspective berupa hasil pentautan kedua citra masukan.

\section{3.1 Konversi Citra ke Grayscale}

Tahap awal sebelum proses pengolahan citra adalah mengonversikan citra dari RGB ke grayscale. Tahap ini diawali dengan pembacaan citra masukan. Sistem akan berjalan apabila terdeteksi dua buah citra masukan pada direktori. Kedua citra tersebut adalah citra uji dan citra acuan. Masing-masing citra masukan merupakan citra RGB, ketika kedua citra terdeteksi, maka 
dilakukan proses konversi RGB ke grayscale. Keadaan awal citra terdiri dari 3 lapisan matrik, yaitu $R$-layer, $G$-layer dan B-layer. Kondisi citra dengan 3 lapisan matrik RGB ini membuat proses-proses dalam pengolahan selanjutnya harus memperhatikan ketiga lapisan matriks tersebut. Bila setiap proses perhitungan harus memperhatikan 3 layer, maka harus dilakukan 3 perhitungan yang sama hal ini memerlukan waktu yang relatif lama, sehingga untuk meminimalisir proses perhitungan pengolahan citra yakni dengan penggunaan citra dalam kondisi grayscale. Citra grayscale hanya memiliki derajat keabuan. Derajat keabuan pada citra grayscale merupakan nilai rata-rata dari $R$-layer, $G$-layer dan B-layer. Program akan dihentikan jika tidak terdeteksi citra masukan. Gambar 3 menunjukkan diagram alir konversi citra ke grayscale.

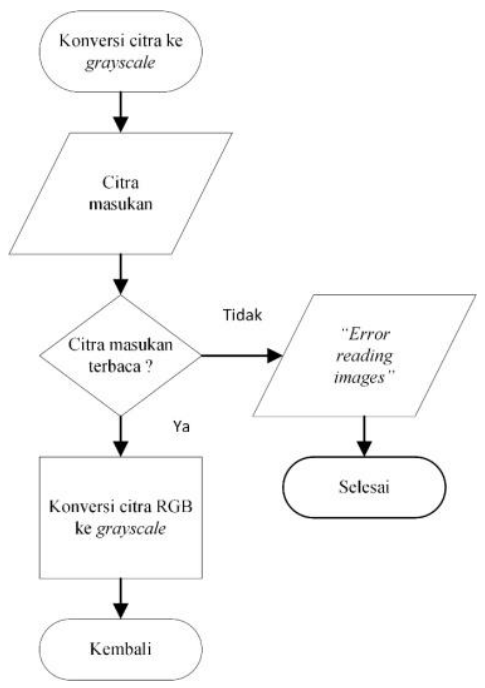

Gambar 3 Diagram alir konversi citra ke grayscale

\section{3.2 Deteksi Keypoint}

Hasil konversi RGB ke grayscale kemudian dilanjutkan dengan pendeteksian keypoint. Fitur gelembung (blob-like feature) digunakan untuk mendeteksi keypoint. Langkah yang dilakukan adalah membentuk piramida citra dengan menggunakan box filter sebagai aproksimasi dari turunan parsial kedua dari Gaussian. Ketika membentuk scale space, citra asli dikonvolusikan pada kotak filter dengan mengubah ukuran kotak filter sesuai dengan citra dan membentuk scale space image [4,7].

Langkah berikutnya adalah mencari ekstrema dari determinan matriks Hessian dibandingkan dengan tetangga-tetangganya. Lokalisasi calon fitur kemudian dilakukan pada setiap ruang skala (scale space) dengan menggunakan non-maximum suppression terhadap eksterma dari determinan matriks Hessian. Hasil akhir dari tahap ini adalah titik-titik acuan atau keypoint yang menunjukkan adanya fitur gelembung (blob-like feature) [4,7]. Gambar 4 menunjukkan proses pendeteksian fitur dengan SURF.

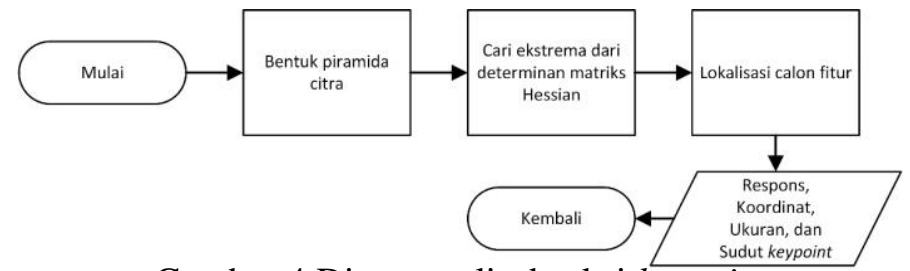

Gambar 4 Diagram alir deteksi keypoint 


\section{3.3 Reduksi Jumlah Keypoint}

Hasil dari deteksi keypoint pada citra kemudian akan direduksi jumlahnya dengan cara mencari nilai jarak antara keypoint pertama yang berperan sebagai keypoint acuan dengan keypoint berikutnya yang berperan sebagai keypoint tetangga. Kemudian jarak tersebut akan dibandingkan dengan nilai radius minimal yang akan divariasikan.

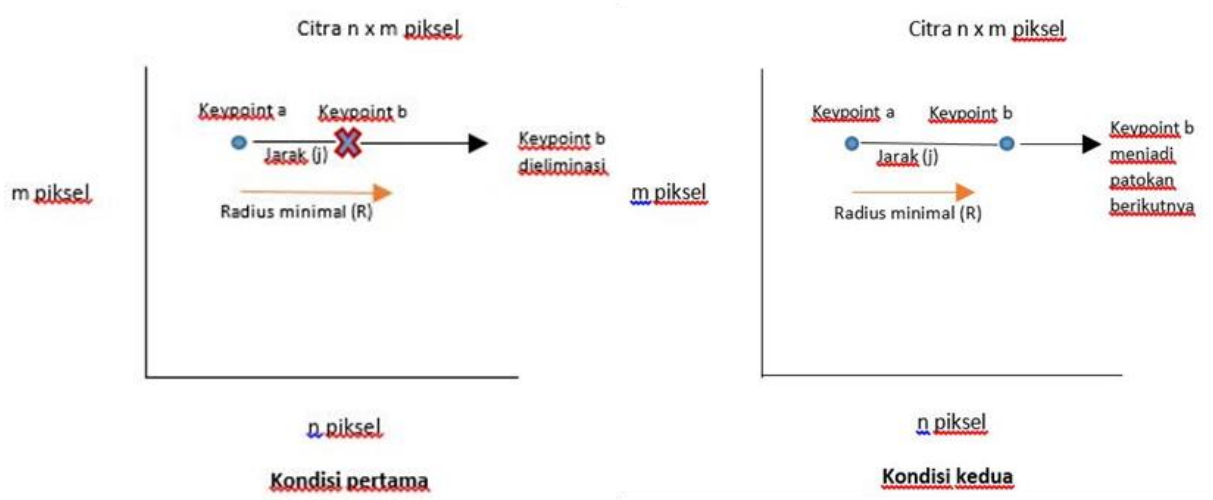

Gambar 5 Proses eliminasi keypoint

Berdasarkan Gambar 5 :

- Jika jarak antara keypoint a dengan b lebih kecil sama dengan radius minimal ( $\mathrm{j} \leq$ $\mathrm{R})$, maka keypoint $\mathrm{b}$ dieliminasi.

- Sebaliknya, Jika jarak antara keypoint a dengan b lebih besar dari radius minimal $(\mathrm{j}>\mathrm{R})$, maka keypoint $\mathrm{b}$ tidak dieliminasi dan menjadi keypoint patokan berikutnya.

Gambar 6 menunjukkan diagram alir proses reduksi jumlah keypoint.

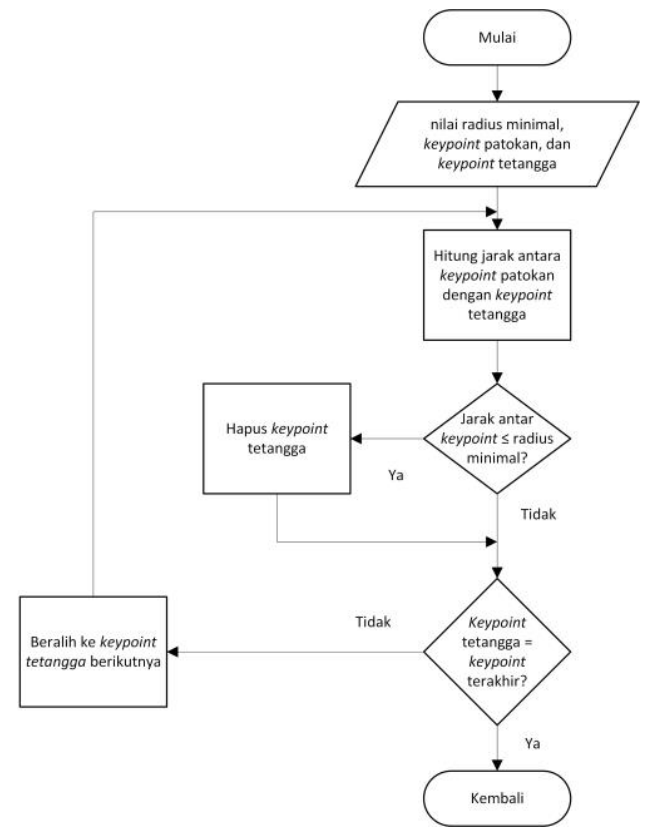

Gambar 6 Diagram alir reduksi jumlah keypoint 


\section{3.4 Deskripsi Keypoint}

Pendeskripsian keypoint diawali dengan menghitung respon Haar-wavelet terhadap sumbu-x dan sumbu-y dengan titik-titik di lingkungan tetangganya pada radius $6 s$ di sekitar titik-titik fitur, dengan $s$ adalah skala pada titik fitur yang terdeteksi seperti pada Gambar 7. Langkah sampling tiap skala adalah $s$ dari masing-masing skala begitu juga perhitungan respon wavelet-nya sesuai dengan skalanya sehingga pada skala yang besar ukuran dari wavelet akan besar pula. Perhitungan citra integral digunakan untuk penapisan yang cepat. Dengan demikian hanya dibutuhkan enam operasi untuk menghitung respon pada sumbu-x dan sumbu-y di setiap skala [4].
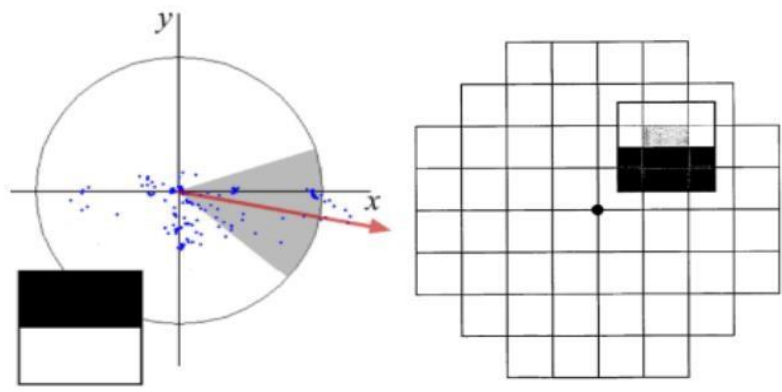

Gambar 7 Pemberian orientasi [4]

Langkah pertama untuk mengekstraksi deskriptor adalah membuat daerah berbentuk bujur sangkar yang berpusat di sekitar titik fitur dan orientasinya mengarah ke orientasi yang sudah ditentukan sebelumnya. Ukuran dari jendela bujur sangkar tersebut adalah 20s. Setiap wilayah kemudian dibagi lagi ke dalam 4 x 4 sub-area. Pada bagian ini disimpan informasi spasial. Perhitungan Haar Wavelet kemudian dilakukan pada setiap sub-area dengan membaginya ke dalam 5 x 5 ruang sampel. Pada umumnya, $d x$ disebut sebagai respon Haar pada arah horizontal dan $d y$ sebagai Haar wavelet pada arah vertikal. Peningkatan robustness ketika terjadi transformasi geometrik dan kesalahan lokal, respon di $d x$ dan $d y$ difokuskan pada pusat Gaussian di keypoint [4]. Persamaan berikut menunjukkan vektor 4D yang diperoleh: $V=\left(\Sigma d_{x}, \Sigma\left|d_{x}\right|, \Sigma d_{y}, \Sigma\left|d_{y}\right|\right)$

Bila ditempatkan pada masing-masing 4 x 4 sub-area akan didapatkan vektor deskriptor dengan panjang 64. Respon wavelet bervariasi terhadap perubahan iluminasi [4]. Faktor skala didapatkan dengan merubah deskriptor ke dalam vektor unit seperti pada Gambar 8.

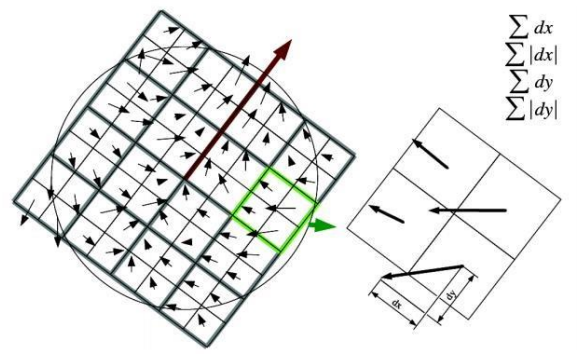

Gambar 8 Komposisi deskriptor keypoint [4]

\section{3.5 Metode FLANN}

Metode Fast Library Approximated Nearest Neighbor (FLANN) adalah sebuah pustaka untuk melakukan pencarian cepat, perkiraan neighborhood, yang terdapat pada space dimensi yang tinggi. Pustaka ini merupakan kumpulan algoritme yang bekerja dengan baik untuk menemukan nilai tetangga terdekat, sementara untuk hasil parameter yang optimal, tergantung pada kumpulan data yang digunakan. Fitur SURF terdiri dari keypoint, deskriptor, dan berupa vektor. Satu citra di basis data memiliki banyak klaster untuk fitur SURF. Klaster ini dibuat 
otomatis dengan menggunakan KNN (K-Nearest Neighbor) dengan tipe indeks KD tree, dimana KNN ini akan mencari jarak yang paling kecil antara vektor fitur dengan vektor pada klaster [8].

Proses pencocokkan fitur pada citra query dan fitur pada citra dalam basis data, vektor keypoint, dan deskriptor pada gambar query akan dicocokkan nilainya menggunakan KNN search. KNN search akan mencari klaster pada basis data yang nilai vektor deskriptornya paling dekat jaraknya dengan vektor deskriptor pada citra query. Setelah klaster didapat, kemudian akan dicari nilai vektor deskriptor pada klaster tersebut yang sama atau paling dekat dengan vektor deskriptor pada citra query. Jika ada yang sama maka ada satu keypoint yang cocok antara kedua citra tersebut. Semakin banyak jumlah keypoint yang cocok, maka dianggap paling baik dalam mendeteksi titik fitur [8].

\section{3.6 Algoritme RANSAC}

Metode RANSAC (Random Sample Consensus) digunakan untuk keypoint yang telah dicocokkan pada matching keypoint. Metode ini juga dapat menentukan inlier dan outlier. Inlier adalah titik yang kira-kira disambungkan menjadi garis, sedangkan outlier adalah titik yang tidak disambungkan menjadi garis. Titik-titik inlier dari sampel poin acak kemudian dipilih oleh RANSAC untuk digabungkan menjadi sebuah garis. Algoritme RANSAC ini sangat bergantung dengan hasil dari tahap sebelumnya. Hal ini bertujuan untuk memperoleh pasangan kecocokan keypoint yang benar-benar sama [9]. Penggambaran algoritme RANSAC diberikan pada Gambar 9:
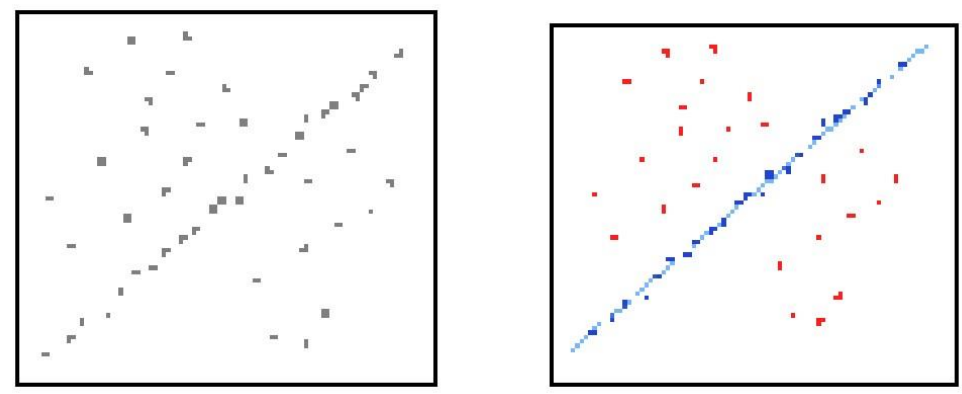

Gambar 9 Gambaran tentang RANSAC. Kiri : kumpulan dengan banyak outlier. Kanan : kumpulan data setelah proses RANSAC [9]

\section{3.7 Pentautan Citra dengan warpPerspective}

Proses warping citra merupakan tahapan terakhir pada sistem pentautan citra yang diolah. Pada awal tahapan ini dilakukan pencarian pola kesamaan kedua citra atau matriks homograf menggunakan RANSAC. Penggunaan RANSAC dilakukan dengan menghilangkan bagian yang tidak cocok hingga didapatkan pasangan yang benar-benar sama yang membentuk suatu pola. RANSAC memiliki kemampuan untuk menghilangkan outliers yang ditemukan sehingga inliers yang diperoleh dapat digunakan sebagai penentuan pola kesamaan yang maksimal. Dari tahapan ini kemudian dilakukan pentautan kedua citra masukan menggunakan warpPerspective berdasarkan pola kesamaannya. Bagian keypoints atau pasangan keypoints yang sama akan saling bertautan sehingga bagian yang memiliki kesamaan akan ditumpuk. Hasil dari proses inilah yang berupa citra hasil pentautan atau citra mozaik [10].

\subsection{Rencana Pengujian}

Pengujian dilakukan untuk mengetahui nilai radius minimal yang dapat digunakan untuk mereduksi jumlah keypoint citra. Pada penelitian ini terdapat tiga variasi pengujian, yaitu variasi rotasi, skala, dan overlap citra. Citra yang diuji memiliki ukuran 1100 x 1500 piksel.

Pada setiap pengujian, jumlah keypoint setelah direduksi, lama waktu komputasi, dan kesuksesan pentautan citra dicatat untuk dianalisis hasilnya. Gambar 10 menunjukkan ilustrasi pengujian variasi citra. 

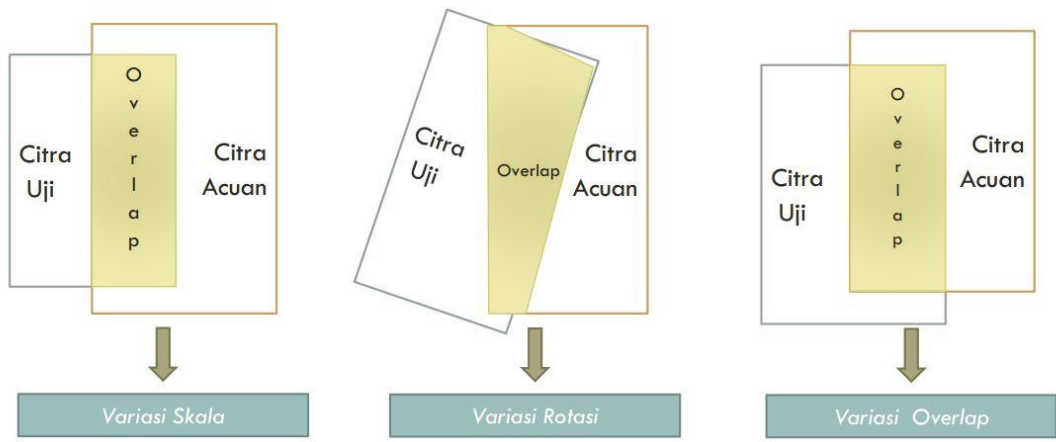

Gambar 10 Ilustrasi pengujian variasi citra

\section{HASIL DAN PEMBAHASAN}

Pada bagian ini dipaparkan hasil pengujian serta pembahasannya yang telah dijabarkan pada sub bab 2.4.

\subsection{Hasil Pengujian Variasi Radius Minimal}

Variasi nilai radius minimal yang digunakan diperoleh dari proses trial and error, yaitu dimulai dari 5 piksel hingga 100 piksel dengan interval 5 piksel per kenaikan nilainya. Nilainilai tersebut diperoleh dan ditetapkan berdasarkan kriteria berikut:

1. Jumlah keypoint yang direduksi sudah tidak signifikan.

2. Jumlah keypoint yang cocok.

3. Keberhasilan pentautan citra.

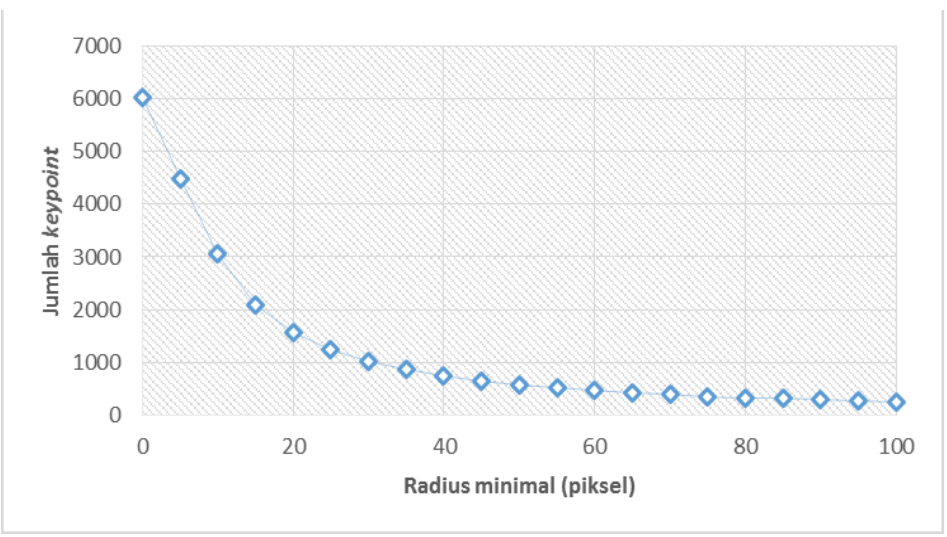

Gambar 11 Grafik jumlah keypoint citra

Berdasarkan pada Gambar 11, metode reduksi data mampu mereduksi jumlah keypoint sekitar 25\% dari jumlah awal pada nilai radius minimal 5 piksel. Kemudian jumlah keypoint tereduksi sekitar 50\% hingga 75\% dari jumlah awal pada nilai radius minimal 10 piksel hingga 20 piksel. Jumlah keypoint tereduksi sekitar $90 \%$ pada nilai radius minimal 40 piksel hingga 50 piksel. Sementara jumlah keypoint yang tereduksi mulai tidak signifikan pada nilai radius minimal 55 piksel hingga 100 piksel, yaitu sekitar $1 \%$ per kenaikan nilai radius minimalnya.

\subsection{Hasil Pengujian Skala}

Pengujian dengan variasi skala ini bertujuan untuk mengetahui pengaruh nilai radius minimal terhadap waktu komputasi dan hasil pentautan citra masukan. Perubahan skala didapat dari perubahan yang dilakukan oleh perangkan lunak pengolah citra. Pengujian ini dilakukan dengan memasukkan citra uji yang memiliki ukuran skala bervariasi dari $50 \%$ hingga $350 \%$ 
dengan kenaikan setiap 10\% dan citra acuan dengan skala sebesar 100\%. Tabel 2 menunjukkan sebagian hasil pengujian skala.

Tabel 1 Hasil pengujian skala

\begin{tabular}{|c|c|c|c|c|c|c|c|c|c|}
\hline & \multirow{2}{*}{$\begin{array}{c}\text { Radius } \\
\text { Skala } \\
(\%)\end{array}$} & $\begin{array}{c}\text { Minimal } \\
\text { Optimum } \\
\text { (piksel) }\end{array}$ & \multicolumn{2}{|c|}{$\begin{array}{c}\text { Keypoint Citra } \\
\text { Acuan }\end{array}$} & \multicolumn{2}{|c|}{$\begin{array}{c}\text { Keypoint Citra } \\
\text { Uji }\end{array}$} & \multicolumn{2}{c|}{ Good Matches } & \multicolumn{2}{c|}{ Waktu (s) } \\
\cline { 3 - 10 } & SUR & $\begin{array}{c}\text { SURF } \\
\text { \& RD }\end{array}$ & SURF & $\begin{array}{c}\text { SURF } \\
\text { \& RD }\end{array}$ & SURF & $\begin{array}{c}\text { SURF } \\
\text { \& RD }\end{array}$ & SURF & $\begin{array}{c}\text { SURF } \\
\text { \& RD }\end{array}$ \\
\hline 50 & 40 & 6020 & 749 & 2998 & 316 & 31 & 4 & 4,71 & 2,72 \\
\hline 100 & 75 & 6020 & 359 & 7848 & 412 & 1774 & 15 & 6,30 & 3,48 \\
\hline 150 & 70 & 6020 & 397 & 6656 & 412 & 24 & 9 & 5,57 & 3,19 \\
\hline 200 & 60 & 6020 & 467 & 5117 & 449 & 8 & 7 & 5,29 & 2,90 \\
\hline 250 & 60 & 6020 & 467 & 3942 & 411 & 14 & 4 & 4,96 & 2,71 \\
\hline 300 & 40 & 6020 & 749 & 3092 & 594 & 16 & 8 & 4,81 & 2,80 \\
\hline 350 & 35 & 6020 & 865 & 2565 & 659 & 8 & 5 & 3,50 & 2,89 \\
\hline
\end{tabular}

Hasil dari pengujian skala menunjukkan kisaran nilai optimum berada pada 25 piksel hingga 100 piksel dengan rata-rata 53,71 piksel. Proses reduksi jumlah keypoint dapat menghasilkan selisih waktu komputasi pentautan citra dengan rata-rata $2,13 \mathrm{~s}$

\subsection{Hasil Pengujian Rotasi}

Pengujian dengan variasi rotasi ini bertujuan untuk mengetahui pengaruh nilai radius minimal terhadap waktu komputasi dan hasil pentautan citra masukan. Perubahan rotasi didapat dari perubahan yang dilakukan oleh perangkan lunak pengolah citra. Pengujian ini dilakukan dengan memasukkan citra uji yang sudutnya diputar $10^{\circ}$ hingga $350^{\circ}$ searah jarum jam dengan kenaikan setiap $10^{\circ}$ serta sudut kritis $1^{0}$ hingga $9^{\circ}$ dan $351^{\circ}$ hingga $359^{\circ}$ sementara citra acuan memiliki putaran sebesar $0^{\circ}$. Pentautan citra dikatakan berhasil apabila citra yang dihasilkan mampu mentautkan potongan dengan benar, walaupun tidak keseluruhan citra yang tertaut, Tabel 2 menunjukkan hasil sebagian pengujian rotasi.

Tabel 2 Hasil pengujian rotasi

\begin{tabular}{|c|c|c|c|c|c|c|c|c|c|}
\hline \multirow{2}{*}{$\begin{array}{c}\text { Rotasi } \\
\mathbf{(}^{\mathbf{(}}\end{array}$} & $\begin{array}{c}\text { Radius } \\
\text { Minimal } \\
\text { Optimum } \\
\text { (piksel) }\end{array}$ & \multicolumn{2}{|c|}{$\begin{array}{c}\text { Keypoint Citra } \\
\text { Acuan }\end{array}$} & \multicolumn{2}{|c|}{$\begin{array}{c}\text { Keypoint Citra } \\
\text { Uji }\end{array}$} & \multicolumn{2}{c|}{ Good Matches } & \multicolumn{2}{c|}{ Waktu (s) } \\
\cline { 3 - 10 } & SURF & $\begin{array}{c}\text { SURF } \\
\text { \& RD }\end{array}$ & SURF & $\begin{array}{c}\text { SURF } \\
\text { \& RD }\end{array}$ & SURF & $\begin{array}{c}\text { SURF } \\
\text { \& RD }\end{array}$ & SURF & $\begin{array}{c}\text { SURF \& } \\
\text { RD }\end{array}$ \\
\hline 0 & 75 & 6020 & 359 & 7848 & 412 & 1774 & 15 & 6,3 & 3,48 \\
\hline 30 & 70 & 6020 & 397 & 6534 & 379 & 4 & 16 & 5,87 & 3,65 \\
\hline 60 & 100 & 6020 & 259 & 6365 & 247 & 7 & 6 & 5,81 & 3,12 \\
\hline 90 & 75 & 6020 & 359 & 6059 & 315 & 1305 & 4 & 5,81 & 3,44 \\
\hline 120 & 100 & 6020 & 259 & 6447 & 244 & 18 & 7 & 5,63 & 3,58 \\
\hline 150 & 45 & 6020 & 643 & 6743 & 653 & 16 & 6 & 5,29 & 3,72 \\
\hline 180 & 95 & 6020 & 266 & 7840 & 306 & 1899 & 5 & 6,29 & 3,78 \\
\hline 210 & 40 & 6020 & 749 & 6461 & 755 & 10 & 8 & 5,97 & 3,93 \\
\hline 240 & 40 & 6020 & 749 & 6363 & 715 & 5 & 9 & 5,72 & 3,91 \\
\hline 270 & 95 & 6020 & 266 & 6045 & 235 & 1323 & 5 & 5,68 & 3,31 \\
\hline 300 & 65 & 6020 & 433 & 6429 & 407 & 10 & 29 & 5,61 & 3,72 \\
\hline 330 & 55 & 6020 & 525 & 6784 & 516 & 6 & 15 & 5,72 & 3,66 \\
\hline
\end{tabular}

Hasil dari pengujian rotasi menunjukkan kisaran nilai optimum berada pada 40 piksel hingga 100 piksel dengan rata-rata 70,74 piksel. Proses reduksi jumlah keypoint dapat menghasilkan selisih waktu komputasi pentautan citra dengan rata-rata 2,19s.

\subsection{Hasil Pengujian Overlap}

Pengujian dengan variasi overlap ini bertujuan untuk mengetahui pengaruh nilai radius minimal terhadap waktu komputasi dan hasil pentautan citra masukan. Perubahan overlap didapat dari perubahan yang dilakukan oleh perangkan lunak pengolah citra. Pengujian ini 
dilakukan dengan memasukkan citra uji yang memiliki ukuran overlap bervariasi dari $10 \%$ hingga $90 \%$ secara horizontal dan 10\% hingga 100\% secara vertikal dengan kenaikan setiap $10 \%$ dan citra acuan dengan skala sebesar 100\%. Tabel 3 dan Tabel 4 menunjukkan sebagian hasil pengujian overlap.

Tabel 3 Hasil pengujian overlap horizontal

\begin{tabular}{|c|c|c|c|c|c|c|c|c|c|c|}
\hline \multicolumn{2}{|c|}{ Overlap (\%) } & \multirow{2}{*}{$\begin{array}{c}\text { Radius } \\
\text { Minimal } \\
\text { Optimum } \\
\text { (piksel) }\end{array}$} & \multicolumn{2}{|c|}{$\begin{array}{c}\text { Keypoint Citra } \\
\text { Acuan }\end{array}$} & \multicolumn{2}{|c|}{$\begin{array}{c}\text { Keypoint Citra } \\
\text { Uji }\end{array}$} & \multicolumn{2}{|c|}{ Good Matches } & \multicolumn{2}{|c|}{ Waktu (s) } \\
\hline $\mathbf{H}$ & $\mathbf{V}$ & & SURF & $\begin{array}{l}\text { SURF } \\
\text { \& RD }\end{array}$ & $\begin{array}{c}\text { SUR } \\
\mathbf{F}\end{array}$ & $\begin{array}{l}\text { SUR } \\
\text { F \& } \\
\text { RD }\end{array}$ & $\begin{array}{c}\text { SUR } \\
\mathbf{F}\end{array}$ & $\begin{array}{l}\text { SURF } \\
\text { \& RD }\end{array}$ & SURF & $\begin{array}{l}\text { SURF } \\
\text { \& RD }\end{array}$ \\
\hline 10 & 10 & 15 & 6020 & 2086 & 913 & 286 & 25 & 6 & 3,52 & 2,99 \\
\hline 20 & 20 & 40 & 6020 & 749 & 1681 & 180 & 133 & 8 & 3,83 & 2,54 \\
\hline 30 & 30 & 85 & 6020 & 314 & 2708 & 117 & 306 & 5 & 4,21 & 2,51 \\
\hline 40 & 40 & 70 & 6020 & 397 & 3586 & 194 & 616 & 5 & 4,46 & 2,70 \\
\hline 50 & 50 & 75 & 6020 & 359 & 4264 & 218 & 974 & 5 & 4,80 & 2,82 \\
\hline 60 & 60 & 95 & 6020 & 266 & 4614 & 193 & 1586 & 8 & 4,96 & 2,87 \\
\hline 70 & 70 & 95 & 6020 & 266 & 4744 & 219 & 1792 & 4 & 5,29 & 2,90 \\
\hline 80 & 80 & 90 & 6020 & 296 & 5047 & 250 & 2525 & 9 & 6,09 & 3,37 \\
\hline 90 & 90 & 95 & 6020 & 266 & 5874 & 261 & 3014 & 13 & 5,50 & 3,16 \\
\hline
\end{tabular}

Tabel 4 Hasil pengujian overlap vertikal

\begin{tabular}{|c|c|c|c|c|c|c|c|c|c|c|}
\hline \multicolumn{2}{|c|}{ Overlap (\%) } & \multirow{2}{*}{$\begin{array}{c}\text { Radius } \\
\text { Minimal } \\
\text { Optimum } \\
\text { (piksel) }\end{array}$} & \multicolumn{2}{|c|}{$\begin{array}{c}\text { Keypoint Citra } \\
\text { Acuan }\end{array}$} & \multicolumn{2}{|c|}{$\begin{array}{c}\text { Keypoint Citra } \\
\text { Uji }\end{array}$} & \multicolumn{2}{|c|}{ Good Matches } & \multicolumn{2}{|c|}{ Waktu (s) } \\
\hline $\mathbf{H}$ & $\mathbf{V}$ & & SURF & $\begin{array}{l}\text { SURF } \\
\text { \& RD }\end{array}$ & $\begin{array}{c}\text { SUR } \\
\text { F }\end{array}$ & $\begin{array}{c}\text { SUR } \\
\text { F \& } \\
\text { RD }\end{array}$ & $\begin{array}{c}\text { SUR } \\
\text { F }\end{array}$ & $\begin{array}{l}\text { SURF } \\
\text { \& RD }\end{array}$ & SURF & $\begin{array}{l}\text { SURF } \\
\text { \& RD }\end{array}$ \\
\hline 10 & 10 & 15 & 6020 & 2086 & 858 & 306 & 31 & 6 & 3,87 & 2,8 \\
\hline 20 & 20 & 85 & 6020 & 314 & 1729 & 83 & 205 & 5 & 3,92 & 2,39 \\
\hline 30 & 30 & 95 & 6020 & 266 & 2358 & 99 & 237 & 5 & 4,14 & 2,45 \\
\hline 40 & 40 & 95 & 6020 & 266 & 3139 & 126 & 460 & 4 & 4,36 & 2,56 \\
\hline 50 & 50 & 95 & 6020 & 266 & 3928 & 161 & 808 & 5 & 4,63 & 2,7 \\
\hline 60 & 60 & 100 & 6020 & 259 & 4544 & 177 & 2036 & 12 & 4,91 & 2,87 \\
\hline 70 & 70 & 95 & 6020 & 266 & 5219 & 219 & 1848 & 11 & 5,16 & 3 \\
\hline 80 & 80 & 100 & 6020 & 259 & 5806 & 230 & 2656 & 12 & 5,67 & 3,17 \\
\hline 90 & 90 & 95 & 6020 & 266 & 6150 & 268 & 3034 & 19 & 5,57 & 3,26 \\
\hline
\end{tabular}

Secara keseluruhan, hasil dari pengujian overlap horizontal citra menunjukkan kisaran nilai optimum berada pada 15 piksel hingga 100 piksel dengan rata-rata 77,53 piksel dan hasil dari pengujian overlap vertikal citra menunjukkan kisaran nilai optimum berada pada 15 piksel hingga 100 piksel dengan rata-rata 83,77 piksel. Proses reduksi jumlah keypoint dapat menghasilkan selisih waktu komputasi pentautan citra dengan rata-rata 2,19s pada uji overlap horizontal citra dan rata-rata 1,92 s pada uji overlap vertikal citra.

\subsection{Hasil Perbandingan Waktu Komputasi}

Berdasarkan hasil keseluruhan pengujian terhadap variasi skala, rotasi, dan overlap citra, diperoleh perbandingan rata-rata waktu komputasi algortime SURF dengan menggunakan metode reduksi data dan tanpa menggunakan metode tersebut yang ditunjukkan pada Gambar 12 . 


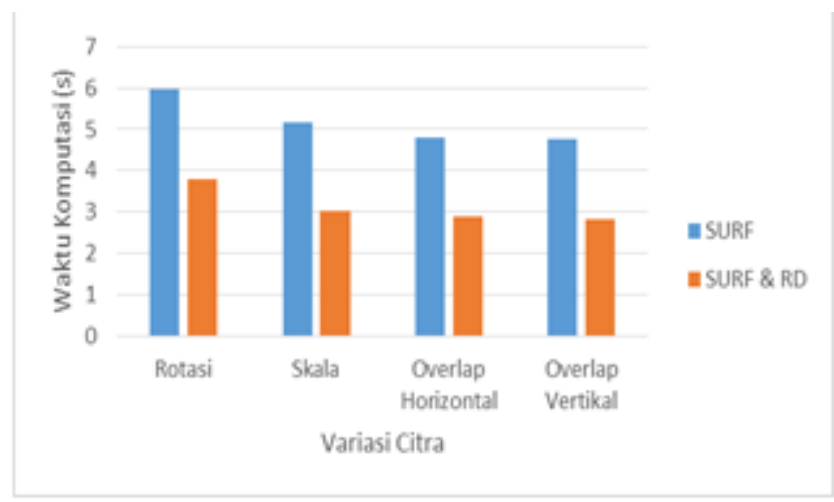

Gambar 12 Grafik perbandingan waktu komputasi menggunakan dan tanpa menggunakan metode reduksi data

Berdasarkan Gambar 12, diketahui metode reduksi data yang diterapkan dapat menghasilkan waktu komputasi pentautan citra dengan rata-rata 39,41\% lebih cepat daripada waktu komputasi pentautan citra tanpa menggunakan metode reduksi data.

\section{KESIMPULAN}

Berdasarkan hasil pengamatan, pengujian, dan analisis pada hasil-hasil yang diperoleh, kesimpulan yang dapat diambil pada penelittian ini adalah:

1. Telah berhasil dibuat implementasi sistem pentautan citra udara menggunakan algoritme SURF dan metode reduksi data dengan melakukan pengujian terhadap variasi skala, rotasi, dan overlap citra.

2. Proses pentautan citra tetap dapat dikerjakan dengan reduksi jumlah keypoint citra hingga $90 \%$ dari jumlah awal keypoint.

3. Metode reduksi data dapat mengurangi waktu komputasi dengan rata-rata $39,41 \%$ dari waktu komputasi tanpa metode reduksi data.

4. Nilai radius minimal yang optimum berada pada rentang 40 hingga 100 piksel.

\section{SARAN}

Diperlukan penelitian lebih lanjut terhadap sistem pentautan citra udara menggunakan algoritme SURF dan metode reduksi data dengan menggunakan lebih dari dua citra masukan dan mengurangi peluang kegagalan pentautan citra dalam penerapan metode reduksi data.

\section{UCAPAN TERIMA KASIH}

Penulis mengucapkan terima kasih kepada semua pihak yang telah memberi bimbingan, dukungan, dan saran selama kegiatan penelitian berjalan.

\section{DAFTAR PUSTAKA}

[1]Wirawan, S., 2014, Sistem Citra Udara Pesawat Tanpa Awak dengan Pentautan Citra, Skripsi, Fakultas Matematika dan Ilmu Pengetahuan Alam, Universitas Gadjah Mada, Yogyakarta.

[2]Dewanti, F., 2015, Purwarupa Sistem Pentautan Citra Udara Pada UAV Menggunakan Algoritme SURF (Speeded-Up Robust Features), Skripsi, Fakultas Matematika dan Ilmu Pengetahuan Alam, Universitas Gadjah Mada, Yogyakarta. 
[3]Sardi, I. L., 2012, Analisis Implementasi Fast Corner Detector pada Image Stitching dalam Pembentuk Citra, Institut Teknologi Telkom, Bandung.

[4]Bay, H., Ess, A., Tuytelaars, T., dan Gool, L. V., 2006, SURF : Speeded-UP Robust Features. Proceeding of 9th European Conference on Computer Vision, Graz, Austria, May 7-13.

[5]Pedersen, J. ,2011, Study Group SURF : Feature Detection \& Description, Aarhus University, Denmark.

[6]Wang, Z.-1., Yan, F.-h., dan Zheng, Y.-y., 2013, An Adaptive Uniform Distribution SURF for Image Stitching, Proceeding of 6th International Congress on Image and Signal Processing (CISP 2013), Hangzhou, December 16-18.

[7]Sukrawan, I., 2008, Pengembangan DSMAC menggunakan Metoda SURF pada Sistem Peluru Kendali dan Komputer, Sekolah Teknik Elektro dan Informatika, Institut Teknologi Bandung, Bandung.

[8] Tania, K. D. dan Arymurthy, A. M., 2010, Tattoo Recognition Based on Speeded Up Robust Features (SURF), University of Sriwijaya, Palembang.

[9]Darajati, Aisah., 2012, Implementasi dan Analisis Citra Mosaik Berbasis Fitur dengan Metode Global Alignment untuk Pembentukan Citra Panorama pada Android, Universitas Telkom, Bandung.

[10]Astuti, R.D., 2011, Sistem Pentautan Foto Udara Menggunakan Deteksi Fiture Algoritma Oriented FAST And Rotated BRIEF, Skripsi, Fakultas Matematika dan Ilmu Pengetahuan Alam, Universitas Gadjah Mada, Yogyakarta. 